\title{
The structural relationships of destination image, awareness, uniqueness and destination loyalty in periurban ecotourism destination
}

DOI 10.1515/ejthr-2016-0023

received 20 May, 2016; accepted 8 November, 2016

\begin{abstract}
This study is designed to explore the conceptualization of ecotourism in order to expand the concept into ecotourism activities in our daily lives. To this end, the author proposes the 'periurban ecotourism' concept and conducts an empirical study with a focus on Nabari City, a small Japanese city with a well-preserved natural environment that has been attracting a number of visitors. In this study, destination image, awareness and uniqueness are presented as key independent variables to set directions for the development as a periurban ecotourism destination and to thereby develop a "theoretical periurban ecotourism model”, and four hypotheses for this study are examined. Findings from the examination reveal that destination image and awareness have a positive impact on overall satisfaction while destination uniqueness generates statistically significant result. In a group of first visitors, however, destination uniqueness appears to have a significant impact of some degree, with less influence than expected. In order to help redefine ecotourism and suggest a variety of research questions for ecotourism markets, it is necessary to conduct an empirical study covering "periurban ecotourism" and its conceptualization, motivation of ecotourists, and lifestyles from a more concrete perspective.
\end{abstract}

Keywords: Periurban ecotourism; Destination loyalty; Destination image

\footnotetext{
*Corresponding author: Kim Sang Jun, Department, Kindai University Associate professor of Business Administration, 3-4-1 Kowakae, Higashiosaka City, 577-8502 Osaka JAPAN Tel.: +81-6-6721-2332, E-mail: ksjum@bus.kindai.ac.jp
}

\section{Introduction}

One of the characteristics of Japan's tourism market is the fact that whilst inbound and outbound international tourism markets are well developed, domestic tours are very active in Japan, compared to many other countries. This is apparent from the 2013 statistics alone; the comparison of the number of Japanese tourists travelling overseas and that of their counterparts in 2013 (Japan Tourism Agency, 2014) shows that the number of overseas travellers was 17.45 million, whilst domestic travellers amounted to 393.46 million (211.55 million one day trips and 181.91 million overnight trips), around 22 times more than overseas travellers in number. Like this, activated local tourism of Japan can be found easily in any region in Japan and from their diverse promotion brochures, maps and pamphlets about tourist resources available. Until now, Japan has managed and provided support for tourist attractions and resources on the basis of local governments, that is, small cities or towns, through policies. In this respect, Japan provides a good environment to perform studies on diverse tourist resources and attractions located in cities and towns from various perspectives. However, it is hard to say that tourism-related studies from various perspectives on cities and towns of Japan are satisfactory now.

One of the key objectives of early research on urban tourism lies in investigating relationships between tourism of an area and products produced in the area and economic impacts (e.g. Bramwell, 1998). Ashworth and Page (2011) classified fields or themes of urban tourism research into 12 sub-themes that have been approached through different methods from viewpoints of sociology and environment preservation as well as economics and business management depending on research areas. However, it has been pointed out that most of such studies tended to lean towards a case study on economic impacts of urban tourism and place imagery with a focus on globally renowned cities, showing several weaknesses such as a lack of theories. In contrast, Pearce (2001) stresses that more systematic and consistent approaches are needed 
in relation to research on urban tourism, arguing that research at city levels can help understand important characteristics of each city and integrate various studies. Keeping these two different perspectives in mind, differences in concepts of urban tourism and the scope and methodology of research on the term can be identified.

This study approaches the concept of urban tourism or the scope of research on the term from a smallest unit viewpoint as possible. In other words, instead of capitals or famous tourist attractions representing countries, this study focuses on a general small city having a population of 10,000 people located near a big city. In particular, the study pays attention to places of small ecotourism or periurban ecotourism having natural tourist resources that citizens of nearby big cities frequently visit for hiking as a one-day trip. As mentioned earlier, in Japan, domestic tourism is very active as local governments and regions promote small- and large-scale tourism activities. The way of choosing the subjects of research in this study is closer to the perspective of Pearce (2001) as discussed above because it is more significant to characterise small cities through more objective statistics at this point in Japan. Amongst others, studies to identify a structural relationship between destination image and satisfaction (e.g. Beerli and Martín, 2004; Chen and Tsai, 2007; Chi and $\mathrm{Qu}, 2008$; Ignacio and Martín, 2008) have not been sufficiently conducted. Therefore, this study empirically examines how destination image, awareness and uniqueness of periurban ecotourism tourists, who visit natural tourist sites near the place they live on one-day trips, have a structural relationship with satisfaction and repeat visits by proposing a theoretical model with the aim of exploring factors significant to sustainable ecotourism development of small Japanese cities. Furthermore, it is also expected to set directions for policies to raise competitiveness of small cities and similar tourist sites and for developing marketing strategies.

\section{Ecotourism and urban ecotourism}

\subsection{Definition of ecotourism}

The term 'ecotourism' first appeared in English language academic literature in the 1980s and has become a key theme of tourist research as it is now since the United Nations declaration of the year 2002 as the International Year of Ecotourism (IYE) and the publication of the Journal of Ecotourism in the same year (Weaver and Lawton, 2007).
Ecotourism was initially defined by international organisations because of the need of mutual cooperation to preserve valuable nature of countries worldwide and promote international tourism exchanges regarding such nature. In 1990, the International Ecotourism Society (TIES) defined ecotourism as follows:

'Ecotourism is responsible travel to natural areas that conserves the environment and improves the well-being of local people' (TIES, 1990)

As far as academic definition of ecotourism is concerned, Buckley (1994) proposed four restrictive frameworks for the definition of ecotourism: nature-based tourism, conservation supporting tourism, environmentally educated tourism and sustainably managed tourism.

Based on the definitions proposed by 25 scholars from the 1980s through the 1990s, Sirakaya et al. (1999) introduced a total of 13 major themes for the definition of ecotourism. ${ }^{1}$ Afterwards, Fennell (2001) listed 85 definitions related to ecotourism, and Donohoe and Needham (2006) suggested six key normative tenets of ecotourism from the findings of a study by Fennell (2001), which are based on nature, preservation/conservation, environmental education, sustainability, distribution of benefits and ethics/ responsibility. Referring to the research by Fennell (2001), Weaver (2001) also defined ecotourism with a focus on three factors: (1) attractive nature, (2) educational effect of interaction between ecotourists and the nature and (3) ecological, socio-cultural and economic sustainability.

\footnotetext{
'Ecotourism is a form of nature-based tourism that strives to be ecologically, socio-culturally, and economically sustainable while providing opportunities for appreciating and learning about the natural environment or specific elements thereof.' (Weaver, 2001, p.105)
}

Weaver (2005) also divided ecotourism into comprehensive type and minimalist type; he argues that the minimalist type is characteristically elemental and natural based (attractions), superficial understanding (learning) and status quo-based (sustainability) and takes soft forms of tourism such as short trips, physically passive activities and multi-purpose visits. In regards to these categories of ecotourism, Wight (1996) reported that hiking placed first in the popular activity package rankings of the North

1 The 13 major themes for the definition of ecotourism are environmental-friendly tourism, responsible travel, educational travel, low-impact travel, recreational and romantic trips to natural sites, contribution to local welfare, ecocultural travel, sustainable/nonconsumptive tourism, responsible-business approach to travel, community involvement, tourist involvement in preservation, buzzword, contribution to conservation. 
American ecotourism market. These findings, although from a study around 20 years ago, indicate that hiking to nearby natural sites that citizens most often and easily do in their daily lives can be included into the category of ecotourism of minimalist type, that is, that of periurban ecotourism.

\subsection{Ecotourism destination and urban ecotourism}

As discussed so far, ecotourism destination research sites are characteristically worldwide primitive natural environments highly valuable to preserve or areas preserved by governments such as national parks. Amongst major ecotourism destinations are primitive natural environments such as Costa Rica and Kenya and national parks such as the Rocky Mountain National Park. In terms of research content, there are studies including one on Costa Rica to suggest directions for the cooperation between policy makers based on the characteristics of ecotourists visiting Costa Rica (Campbell, 1999); a case study about policy process and organization activities relating to ecotourism of Costa Rica (Tepelus and Córdoba, 2005); a study to suggest directions of sustainable policy making for ecotourism via a comparison of magnitudes and situations of ecotourism between Costa Rica and Kenya (Weaver, 1999); a study on propose ecotourism market segmentation on the basis of tourism activities and motivations and characteristics of visitors to Gold Coast in Australia (Weaver and Lawton, 2002); a study that assesses sustainability of ecotourism by presenting achievements of Sabiki in Taiwan in terms of correlation amongst and between 'resource', 'community' and 'tourism' (Tsaur et al., 2006); a study that puts emphasis on the importance of policy-making organisation for sustainable ecotourism by analysing a case of ecotourism community of Hamanaka in Hokkaido, Japan (Shikida et al., 2010); and a study that suggests alternatives of sustainable ecotourism via ecotourism programmes operated by national parks in Korea in connection with forms and magnitudes of national and regional ecotourism (Lee et al., 2012).

Since 2000, the definition of ecotourism has become even broader, and Weaver and Lawton (2002) classified the characteristics of ecotourism into hard (active, deep) and soft (passive, shallow) types, and Weaver (2005) further introduced a new trend of urban ecotourism that offers a variety of programmes covering natural observation and education in urban areas having a specific natural environment, although they are not spectacular primitive natural sites or national parks like the minimal type of ecotourism. This trend aims to accommodate even general tourists who find it difficult to have access to ecotourism and thereby maintain the original purpose of ecotourism, that is, preservation of nature, and have a positive economic and social effect on the area concerned. Higham and Lück (2002) conducted a case study on Blue Penguin Colony, Dolphin Explorer and Karori Wildlife Sanctuary tourism programmes in three cities of New Zealand - Oamaru, Auckland and Wellington - with the aim of evaluating effects of urban ecotourism. In their study, the authors enhance the importance of economic effects by increasing the participation of general tourists for sustained development and survival of ecotourism, whilst observing central elements of ecotourism including preservation of local environments and educational effect.

Even though no academic definition has been established yet, the Green Tourism Association (GTA) of Toronto in Canada defines urban green tourism as follows:

\footnotetext{
'.travel and exploration within and around an urban area that offers visitors enjoyment and appreciation of the city's natural areas and cultural resources, while inspiring physically active, intellectually stimulating and socially interactive experiences; promotes the city's long-term ecological health by promoting walking, cycling, public traffic facilities; promotes sustainable local economic and community development and vitality; celebrates local heritage and the arts; is accessible and equitable to all' (Gibson et al., 2003, p. 324)
}

Gibson et al. (2003) introduced synergy and effects of an urban ecotourism system put in place from 1996 using abundant cultural resources and natural environments, high quality of life and convenient traffic facilities of Toronto, a large Canadian city. Meanwhile, $\mathrm{Wu}$ et al. (2010) assessed the difference between urban ecotourism destination and traditional ecotourism destination of Taiwan in the BNP (best non-fuzzy value) method and presented the dimensions of urban ecotourism. What these two studies have in common is the fact that both of them address the possibility of urban ecotourism as a new trend of ecotourism and directions of its development. Namely, the studies were designed to expand the concept of ecotourism and the scope of industries to which the concept can be applied practically and further create new tourism activities of ecotourism and expand tourism markets in order to enhance effects on the local economy and social contribution.

Considering this trend, this study is based on a broader concept of urban ecotourism destination. Specifically, in a country like Japan that has witnessed activated domestic tourism and boasts of abundant natural resources at 
hand, one-day hiking often and repeatedly enjoyed in daily lives is considered as a form of ecotourism. This type of one-day hiking is also connected to the core concepts required by ecotourism such as preservation of nature, education effect and various exchanges with the community concerned.

Consequently, given the definition of urban ecotourism' by GTA, this study defines small ecotourism or popular ecotourism activity such as hiking in the place of residence over the weekend as 'periurban ecotourism' by moving the scope, that is, the place of urban ecotourism destination to everyday settings.

\section{Theoretical model and hypotheses}

This study sets out empirical analysis results, with a focus on ways of raising the competitiveness of urban ecotourism destination. To this end, this study first applies experimentally three attributes, that is, destination image, awareness and uniqueness, as key influential variables to create competitiveness of urban ecotourism destination and two attributes, namely overall satisfaction and destination loyalty as outcomes. The view point of periurban ecotourism is used in the study to approach the subject matter. Urban ecotourism destinations around small- and medium-level cities in Japan have advantages such as easy access, relatively high frequency of visit and low prices, and therefore, concepts of major attributes that have been used for research on tourism destination so far are also examined in an exploratory manner in relation to urban ecotourism destination in this study.

Destination Image and Overall Satisfaction: Regarding the structural relationship between destination image and satisfaction, Bigné et al. (2001) examined two cities of Spain, Peñíscola and Torrevieja; Chi and Qu (2008) looked into Eureka Springs in the States; and Prayag and Ryan (2012) investigated visitors of Mauritius, a small island state in Africa by applying diverse measurement variables constituting destination images. Meanwhile, Assaker et al. (2011) conducted a study using online survey data on tourists from France, the United Kingdom and Germany, and what made their study different from other researches is that they measured destination image with a single variable that measures the degree of being favourable, instead of attributes. Although application of tools measuring destination image varies amongst scholars, most of the empirical studies were found to have a significant structural relationship between destination image and overall satisfaction; namely, positive results of destination image affected overall satisfaction positively. From these findings, the following hypothesis was set up:
H1. Urban ecotourism destination image positively affects tourists' overall satisfaction.

Destination Awareness and Overall Satisfaction: Research on destination awareness is related to the theory of destination brand recently studied. In studies on general brands, awareness is a key attribute that affects positively dependent variables such as brand value and brand loyalty (Keller, 1993; Aaker, 1996). Such concept of awareness has been theoretically discussed and empirically tackled as a key attribute in brand equity theory in the field of tourism destination and hospitality (Pike, 2007, 2010; Lee and Back, 2008, 2010). Up to now, places famous as ecotourism destinations have enjoyed a high level of awareness. Urban ecotourism destination in this study, however, is a place of periurban ecotourism where reputation stays local. Thus, the following hypothesis was set up to test a structural relationship between ecotourism destination awareness and overall satisfaction in an exploratory way.

H2. Urban ecotourism destination awareness positively affects tourists' overall satisfaction.

Destination Uniqueness and Overall Satisfaction: Destination uniqueness is one of the key attributes that have been applied to brand theory at large like destination awareness. In brand theory, brand uniqueness can be regarded as something special (Netemeyer et al., 2004) that makes a product apparently different from competing goods. If the urban ecotourism destination in this study has special natural sites and attractions drawing attention of visitors and making it stand out, compared to similar urban ecotourism destinations nearby, then positive effects on overall satisfaction will follow. Thus, the following hypothesis was created to examine such a structural relationship in an exploratory manner:

H3. Urban ecotourism destination uniqueness positively affects tourists' overall satisfaction.

Overall Satisfaction and Destination Loyalty: Many studies have reported so far that overall satisfaction as a dependent variable has a strong structural relationship with ultimate dependent variables such as revisit intention and recommend intension (Chen and Tsai, 2007; Hui et al., 2007; Campo-Martínez et al., 2010). Nevertheless, a growing number of case studies have been carried out recently, which integrate ultimate dependent variables such as revisit intention and recommend intension into a single concept of destination loyalty (Yoon and Uysal, 2005; Chi and Qu, 2008; Ignacio and Martín, 2008). In line with these research trends, the author applied the concept of destination loyalty as an ultimate dependent variable and expects that there is a positive structural relationship between overall satisfaction and destination loyalty similar to results from previous studies. Thus the following hypothesis was set up:

H4. Overall satisfaction positively affects destination loyalty. 


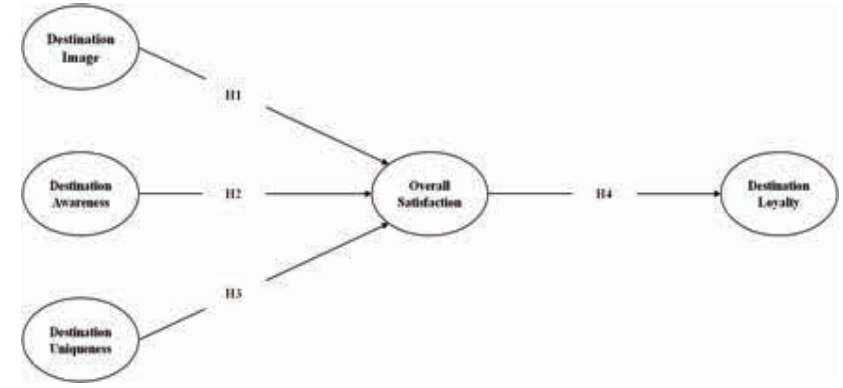

Figure 1: Theoretical Periurban Ecotourism Model

\section{Methodology}

In order to empirically test the structural relationship of destination image, destination awareness, destination uniqueness, overall satisfaction and destination loyalty that constitute the periurban ecotourism model proposed in this study, concepts were defined and measurement items were introduced as follows. Besides, characteristics of Nabari City in Japan, the subject of this study, were investigated and analysed in the following manner.

\subsection{Questionnaire design}

(1) Destination Image: Although many scholars have suggested definitions of destination image, this study adopts the definition of Crompton (1979) and Kotler et al. (1994), that is, 'the sum of beliefs, ideas, and impressions that a person has on a destination." Therefore, urban ecotourism destination image in this study is defined as "the sum of beliefs, ideas, and impressions that a person has on an urban ecotourism destination.' In connection with tourism destination image research, many scholars classify destination image largely into dimensions of cognitive image and affective image (Beerli and Martín, 2004a, 2004b; Ignacio and Martín, 2008), because there are various components of destination image including tourism environments and nature, infrastructure, service quality, events and history and culture. However, given the characteristics of Nabari City, the subject of this study, this study creates measurement variables of urban ecotourism destination image, confining to nature variables. Thus, referring to measurement variables of destination image used for studies of Chen and Tsai (2007) and Chi and Qu (2008), four measurement variables, such as 'scenic mountain and valleys', 'breathtaking scenery and natural attractions', 'picturesque parks/lakes/rivers' and 'unspoiled wilderness and fascinating wildlife', were finally introduced, all of which were evaluated as 1 = strongly disagree and 7 = strongly agree in a seven-point Likert scale.

(2) Destination Awareness: As stated above, recent increases in studies of destination in terms of brand have led destination awareness to become a key independent variable. Boo et al. (2009) suggests in a study about destination brand asset that the dimension of brand awareness is one of the important influential variables. In order to measure awareness about Nabari City, the subject of this study, four measurement variables were generated, referring to studies of Yoo and Donthu (2001), Buil et al. (2008), Lee and Back (2008, 2010), Kim et al. (2008), and Boo et al. (2009). The four measurement variables are 'good reputation', 'very famous', 'the characteristics come to my mind quickly' and 'when I think of tours, this destination comes to my mind immediately', all of which were evaluated as 1 = strongly disagree and 7 = strongly agree in a seven-point Likert scale.

(3) Destination Uniqueness: Destination uniqueness is defined as "'something clearly different from or unique in comparison to other competing destinations felt by visitors', referring to the definition of Netemeyer et al. (2004) regarding brand uniqueness, as mentioned earlier. Accordingly, from studies of Netemeyer et al. (2004), Kemp et al. (2012) and Hsu et al. (2012), which apply destination uniqueness, a measurement variable in this study, to test the value of destination and hospitality using recent brand theory, four measurement variables are produced: 'different from other cities', 'unique in comparison to other cities', 'stands out from other cities' and 'distinct from other cities', all of which were evaluated as $1=$ strongly disagree and $7=$ strongly agree in a seven-point Likert scale.

(4) Overall Satisfaction and Destination Loyalty: Overall satisfaction consists of three measurement variables such as 'natural scenery and atmosphere', 'tourist facilities tourist information and so on' and 'friendly and helpful local people', all of which were evaluated as $1=$ strongly dissatisfactory and $7=$ strongly satisfactory in a seven-point Likert scale. Destination loyalty is composed of two measurement variables - 'intention to revisit' and 'intention to recommend', which were evaluated as $1=$ strongly disagree and $7=$ strongly agree in a seven-point Likert scale. 


\subsection{Research destination}

The periurban ecotourism destination of this study is Nabari City located in Mie Prefecture of Japan. It is a small city having a population of around 80,000 , located between Osaka and Nagoya. Every year, an estimated 400,000 tourists (Nabari City, 2014) visit there, and the major tourist attraction (the Akame 48 waterfalls, Kaochi valleys, Shorenji Lake, etc.) is nature. Most of the visitors are hikers who come to see the autumnal leaves from November through December, and common tourism courses are one-day visits to cultural and historical sites in the city followed by an approximately two-hour tour to forests and waterfalls. Most of the visitors come from nearby large cities, Osaka and Nagoya, and families and individuals often come to visit over the weekend. As it has been chosen as an ecotourism destination by the Japanese government and received government supports under a development plan, Nabari City is very likely to become a place to boost ecotourism in nearby urban areas. Currently, there are diverse experience programmes, education programs and policy tasks to raise the current and future local brand images.

\subsection{Sample and data analysis}

For empirical analysis, seven sessions of face-to-face survey were carried out for about two months from November to December in 2014 at major tourist attractions of Nabari, Mie Prefecture, Japan (The Akame 48 waterfalls,
Kaochi valleys, Shorenji Lake). The survey was a face-toface questionnaire survey directly administered by business majors of Kinki University to visitors to the city. A total of 500 copies of the questionnaire were distributed, and 490 copies were collected, of which 480 copies were used for analysis.

Three analysis methods such as exploratory factor analysis (EFA), confirmatory factor analysis (CFA) and SEM (structure equation analysis) were used to produce empirical results on the structural relationship of periurban ecotourism model, which is the objective of this study. For the analyses, SPSS 22.0 for Windows and AMOS 22.0 program were used.

\section{Empirical result}

The general characteristics of respondents to the survey were summarised in Table 1.

In terms of gender, 199 (41.5\%) were males and 281 (58.5\%) were females, and in terms of age, $123(25.6 \%)$ were in their 10 s to 20 s and $110(22.9 \%)$ were in their 30 s to $40 \mathrm{~s}$ in this order. The most frequent travel party was 'friends' (127 (26.5\%)), followed by 'husband and wife' (116 (24.2\%)) and 'couple' (68 (14.2\%)) in this order. In terms of duration of stay, most of the respondents, 437 (91.0\%), replied 'one-day trip', and when it came to past experience, 'first-time visit' accounted for 268 respondents (55.8\%) and 'repeat visit' for 212 (44.2\%), respectively. In terms of occupation, 'clerical workers or civil

Table 1: Demographic characteristics of respondents

\begin{tabular}{|c|c|c|c|c|c|c|c|}
\hline Contents & & Frequency & Percentage & Contents & & Frequency & Percentage \\
\hline \multirow[t]{2}{*}{ Gender } & Male & 199 & 41.5 & \multirow{2}{*}{$\begin{array}{l}\text { Duration of } \\
\text { stay }\end{array}$} & Overnight trip & 43 & 9.0 \\
\hline & Female & 281 & 58.5 & & One-day trip & 437 & 91.0 \\
\hline \multirow[t]{4}{*}{ Age } & $10-20$ & 123 & 25.6 & \multirow{2}{*}{$\begin{array}{l}\text { Past } \\
\text { experience }\end{array}$} & First-time visit & 268 & 55.8 \\
\hline & $30-40$ & 110 & 22.9 & & Repeat visit & 212 & 44.2 \\
\hline & $50-60$ & 195 & 40.6 & \multirow[t]{9}{*}{ Occupation } & Student & 46 & 9.6 \\
\hline & 70 and older & 52 & 10.8 & & Clerical worker or civil servant & 164 & 34.2 \\
\hline \multirow{7}{*}{$\begin{array}{l}\text { Travel } \\
\text { party }\end{array}$} & Single & 45 & 9.4 & & Teacher & 4 & .8 \\
\hline & Family & 50 & 10.4 & & Self-employed & 40 & 8.3 \\
\hline & Husband and wife & 116 & 24.2 & & Skilled worker & 20 & 4.2 \\
\hline & Couple & 68 & 14.2 & & Homemaker & 125 & 26.0 \\
\hline & Friends & 127 & 26.5 & & Culture or art field & 1 & .2 \\
\hline & Tour group & 57 & 11.9 & & Technology or science field & 3 & .6 \\
\hline & Other & 17 & 3.5 & & Other & 77 & 16.0 \\
\hline
\end{tabular}


servants' accounted for 164 (34.2\%) and 'homemakers' for $125(26.0 \%)$.

\subsection{Exploratory Factor Analysis (EFA)}

Table 2 shows the results of EFA aiming to examine content validity of measurement variables of destination image, awareness and uniqueness as independent variables of this study.

Factor loading of variables belonging to each measurement dimension was 0.6 or higher, exceeding 0.5 required by general social sciences, and the variables were found to be key variables to explain each measurement dimension. Criteria for the statistical significance of EFA results were found to be $\mathrm{KMO}=0.853$ (0.7 or higher) and Bartlett $=4,059.614(P<0.01)$, which are very good. Furthermore, values of Cronbach's $\alpha$ to test the reliability of measurement variables belonging to each measurement dimension were all 0.8 or higher, indicating that measurement variables explaining each measurement dimension have a high degree of reliability.

\subsection{Confirmatory Factor Analysis (CFA)}

Next, Table 3 describes the results of CFA to test validity and reliability of all measurement variables explaining overall satisfaction and destination loyalty as dependent variables and destination image, awareness and uniqueness as independent variables of this study and confirmatory measurement model.

As a result of CFA, standard factor loading of measurement variables by measurement dimension were all found to be 0.6 or over, confirming construct validity. Moreover, AVE (average variance extracted) results show that 'destination image' (0.760), 'destination awareness' (0.550), 'destination uniqueness' (0.724), 'overall satisfaction' (0.621) and 'destination loyalty' (0.824) exceeded the reference 0.5 , confirming convergent validity. In addition, construct reliability was 0.926 for 'destination image', 0.830 for 'destination awareness' , 0.913 for 'destination uniqueness', 0.895 for 'overall satisfaction' and 0.903 for 'destination loyalty', respectively, all of which exceeded the reference of 0.7 indicating high reliability, or internal consistency.

Table 2: Result of Exploratory Factor Analysis (EFA)

\begin{tabular}{|c|c|c|c|c|}
\hline Factor/item & $\begin{array}{l}\text { Factor } \\
\text { loading }\end{array}$ & Eigen value & $\begin{array}{l}\text { Variance } \\
\text { explained } \\
(\%)\end{array}$ & $\begin{array}{l}\text { Cronbach's } \\
\alpha\end{array}$ \\
\hline Destination Image & & 4.710 & 39.25 & 0.931 \\
\hline 1. Scenic mountain and valleys & 0.913 & & & \\
\hline 2. Breathtaking scenery and natural attractions & 0.942 & & & \\
\hline 3. Picturesque parks/lakes/rivers & 0.860 & & & \\
\hline 4. Unspoiled wilderness and fascinating wildlife & 0.912 & & & \\
\hline Destination Awareness & & 3.332 & 27.77 & 0.830 \\
\hline 1. This destination has a good reputation & 0.754 & & & \\
\hline 2. This destination is very famous & 0.814 & & & \\
\hline 3. The characteristics of this destination come to my mind quickly & 0.819 & & & \\
\hline 4. When I think about tours, this destination comes to my mind immediately & 0.678 & & & \\
\hline Destination Uniqueness & & 1.145 & 9.54 & 0.905 \\
\hline 1. This destination is different from other cities & 0.797 & & & \\
\hline 2. This destination is unique in comparison to other cities & 0.883 & & & \\
\hline 3. This destination stands out from other cities & 0.804 & & & \\
\hline 4. This destination is distinct from other cities & 0.865 & & & \\
\hline
\end{tabular}

$\star * \mathrm{KMO}=0.853 /$ Bartlett $=4,059.614 /$ Significance $=0.000$ 
Values of overall goodness of fit of measurement model of CFA were $\chi^{2} / \mathrm{df}=2.839(295.304 / 104, p<0.01)$, $\mathrm{RMR}=0.110, \mathrm{RMSEA}=0.062$, GFI $=0.929, \mathrm{AGFI}=0.896$, PGFI $=0.632, \mathrm{NFI}=0.948, \mathrm{RFI}=0.933$ and $\mathrm{CFI}=0.966 . \mathrm{In}$ comparison with criteria for goodness of fit, it was found that the values fall short of goodness of fit are generally acceptable at RMR $(<0.05)$ and AGFI $(>0.9)$ to some degree. They were also found to have overall significant levels of goodness of fit in terms of other criteria for goodness of fit such as RMSEA, GFI, PGFI, NFI, RFI and CFI. Thus, the overall goodness of fit of measurement model appeared to be acceptable.

\subsection{Estimated structural model}

For the analysis to test the structural model and its hypotheses, all-participants data and those of the 'first visitor' and 'repeat visitor' groups were used, respectively. The analysis using all-participants data was designed to test hypotheses set in this study, and the analysis on the first visitor and repeat visitor groups for whom the visit to Nabari was the second time or more, respectively, aimed to investigate any difference between the groups in the structural relationship with theoretical urban ecotourism model and to thereby find implications on the two groups.

Goodness-of-fit indices of theoretical urban ecotourism model are given in Table 4. Goodness-of-fit indices for all-participants data are $\chi^{2} / \mathrm{df}=2.300(731.511 / 318), \mathrm{RMR}$

Table 3: Result of Confirmatory Factor Analysis (CFA)

\begin{tabular}{|c|c|c|c|c|c|c|}
\hline Factor/item & $\begin{array}{l}\text { Factor } \\
\text { loading }\end{array}$ & S. E & t-value & $\begin{array}{l}\text { Std. } \\
\text { Factor } \\
\text { loading }\end{array}$ & CR & AVE \\
\hline Destination Image & & & & & 0.926 & 0.760 \\
\hline 1. Scenic mountain and valleys & 1.000 & & & 0.845 & & \\
\hline 2. Breathtaking scenery and natural attractions & 0.844 & 0.035 & $24.321 * \star \star$ & 0.761 & & \\
\hline 3. Picturesque parks/lakes/rivers & 1.129 & 0.038 & $29.580^{\star \star \star}$ & 0.971 & & \\
\hline 4. Unspoiled wilderness and fascinating wildlife & 1.072 & 0.040 & $26.529 * \star \star$ & 0.897 & & \\
\hline Destination Awareness & & & & & 0.830 & 0.550 \\
\hline 1. This destination has a good reputation & 1.000 & & & 0.664 & & \\
\hline 2. This destination is very famous & 1.103 & 0.073 & $15.108^{\star * \star}$ & 0.714 & & \\
\hline 3. The characteristics of this destination come to my mind quickly & 1.170 & 0.087 & $13.436 * * \star$ & 0.829 & & \\
\hline $\begin{array}{l}\text { 4. When I think about tours, this destination comes to my mind } \\
\text { immediately }\end{array}$ & 1.053 & 0.086 & $12.279^{\star \star \star}$ & 0.751 & & \\
\hline Destination Uniqueness & & & & & 0.913 & 0.724 \\
\hline 1. This destination is different from other cities & 1.000 & & & 0.843 & & \\
\hline 2. This destination is unique in comparison to other cities & 1.045 & 0.046 & $22.770^{\star \star \star}$ & 0.862 & & \\
\hline 3. This destination stands out from other cities & 1.019 & 0.042 & $24.161^{\star \star \star}$ & 0.863 & & \\
\hline 4. This destination is distinct from other cities & 0.982 & 0.045 & $21.605^{\star \star \star}$ & 0.835 & & \\
\hline Overall Satisfaction & & & & & 0.895 & 0.621 \\
\hline 1. Natural scenery and atmosphere & 1.000 & & & 0.761 & & \\
\hline 2. Tourist facilities (tourist information etc.) & 0.991 & 0.069 & $14.345^{\star \star \star}$ & 0.746 & & \\
\hline 3. Friendly and helpful local people & 1.381 & 0.092 & $14.984^{\star \star \star}$ & 0.852 & & \\
\hline Destination Loyalty & & & & & 0.903 & 0.824 \\
\hline 1.Intentiont to revisit & 1.000 & & & 0.913 & & \\
\hline 2. Intention to recommend & 0.995 & 0.040 & 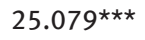 & 0.902 & & \\
\hline
\end{tabular}

$\mathrm{X}^{2} / \mathrm{df}=2.839(295.304 / 104)$

$\mathrm{RMR}=0.110 / \mathrm{RMSEA}=0.062 / \mathrm{GFI}=0.929 / \mathrm{AGFI}=0.896 / \mathrm{PGFI}=0.632 / \mathrm{NFI}=0.948 / \mathrm{RFI}=0.933 / \mathrm{CFI}=0.966$

$\star \star \star p<0.01$ 
$=0.119$, RMSEA $=0.037, \mathrm{GFI}=0.918, \mathrm{AGFI}=0.882, \mathrm{PGFI}=$ $0.636, \mathrm{NFI}=0.937, \mathrm{RFI}=0.919$ and $\mathrm{CFI}=0.963$. The analysis on first visitor and repeat visitor groups revealed that the first visitor group had $\chi^{2} / \mathrm{df}=2.227(236.057 / 106)$, RMR $=0.124, \mathrm{RMSEA}=0.068, \mathrm{GFI}=0.907, \mathrm{AGFI}=0.866, \mathrm{PGFI}$ $=0.628, \mathrm{NFI}=0.929, \mathrm{RFI}=0.908$ and $\mathrm{CFI}=0.959$, and the repeat visitor group had $\chi^{2} / \mathrm{df}=2.047(216.981 / 106), \mathrm{RMR}$ $=0.117$, RMSEA $=0.007, \mathrm{GFI}=0.895, \mathrm{AGFI}=0.849, \mathrm{PGFI}$ $=0.620$, NFI $=0.917$, RFI $=0.893$ and $\mathrm{CFI}=0.955$. Overall goodness-of-fit indices were found to fall short of sufficient goodness of fit in terms of RMR and AGFI to some degree, whilst other goodness-of-fit indices met acceptable levels.

Results of testing the hypotheses proposed by the theoretical periurban ecotourism model are shown in Table 5.

In the analysis of all-participants data, both 'destination image' $(\beta=0.384, P<0.01)$ and 'destination awareness' $(\beta=0.122, p<0.05)$ appeared to have a statistically significant structural relationship with overall satisfaction, thus supporting $\mathrm{H} 1$ and H2. However, the structural relationship of 'destination uniqueness' and 'overall satisfaction' was not found to be statistically significant; thus, H3 was not supported. The structural relationship between 'overall satisfaction' and 'destination loyalty', H4, was found to be extremely high $(\beta=1.106, P<0.01)$, as reported in existing literatures.

On the contrary, the first visitor and repeat visitor groups generated some degree of differences in the analysis. In the case of the first visitor group, 'destination image' ( $\beta=0.338, P<0.01)$ and 'destination uniqueness' ( $\beta=0.130, P<0.1)$ had a statistically significant structural relationship with 'overall satisfaction', whilst in the repeat visitor group, 'destination image' $(\beta=0.402, P<0.01)$ and 'destination awareness' $(\beta=0.210, p<0.05)$ showed a statistically significant structural relationship with 'overall satisfaction'. The structural relationship with 'overall satisfaction' and 'destination loyalty' was statistically significant in both groups $(\beta=1.062, \beta=1.225, P<0.01)$.

Consequently, when it came to destination uniqueness, the effect on overall satisfaction turned out to be not statistically significant in this study, contrary to the expectation that in ecotourism destination, uniqueness would serve as an important dimension.

\subsection{Cross-tap analysis}

All participants in this study were divided into the first visitor and repeat visitor groups, and a cross-tap analysis was carried out to test the differences in the characteristics of the two groups, and the results were summarised in Table 6. In terms of 'home', 'travel party', 'motivation', 'traffic facilities', 'occupation' and 'age', the two groups showed statistically significant (Pearson $\chi^{2}, P<0.01$ ) differences in frequency.

In terms of home, the first visitor group appeared to have an overall even distribution, with high frequency in 'Other, Aichi Prefecture' ( $\mathrm{N}=48,17.9 \%)$, whilst the repeat visitor group showed the highest frequency for citizens of 'Mie Prefecture' to which Nabari City belongs ( $\mathrm{N}=86$, 40.6\%).

The most popular travel parties in the first visitor group was found to be 'friends' $(\mathrm{N}=70,26.1 \%)$, 'husband and wife' $(\mathrm{N}=65,24.3 \%)$ and 'couple' $(\mathrm{N}=49,18.3 \%)$ in this order, whereas in the repeat visitor group, 'friends' $(\mathrm{N}$ $=57,26.9 \%)$, 'husband and wife' $(\mathrm{N}=51,24.1 \%)$ and 'tour group' $(\mathrm{N}=36,17.0 \%)$ in this order were mostly selected as travel parties. It is noteworthy that the major travel party was 'couple' for the first visitors and 'tour group' for repeat visitors, respectively.

In terms of motivation, it is important that the first visitor group ranked 'newspaper or magazine' $(\mathrm{N}=25$, 9.3\%) first, which was relatively higher than that in the repeat visitor group. Meanwhile, for the repeat visitor group, 'had a good experience on the last visit' $(\mathrm{N}=84$, $39.6 \%$ ) had an extremely high frequency which is a very high repeat rate of significance.

When it came to traffic facilities, both groups showed high frequencies in 'private automobile', 'Kintetsu Railways' and 'chartered bus' in this order. Here, what

Table 4: Goodness-of-Fit Indices for Theoretical Periurban Ecotourism Model

\begin{tabular}{|c|c|c|c|c|c|c|c|c|c|c|c|}
\hline Model & $x^{2}$ & df & $X^{2} / d f$ & RMR & RMSEA & GFI & AGFI & PGFI & NFI & RFI & CFI \\
\hline $\begin{array}{l}\text { All participants } \\
(\mathrm{N}=480)\end{array}$ & 731.511 & 318 & 2.300 & 0.119 & 0.037 & 0.918 & 0.882 & 0.636 & 0.937 & 0.919 & 0.963 \\
\hline $\begin{array}{l}\text { First visitors } \\
(\mathrm{N}=268)\end{array}$ & 236.057 & 106 & 2.227 & 0.124 & 0.068 & 0.907 & 0.866 & 0.628 & 0.929 & 0.908 & 0.959 \\
\hline $\begin{array}{l}\text { Repeat visitors } \\
(\mathrm{N}=212)\end{array}$ & 216.981 & 106 & 2.047 & 0.117 & 0.007 & 0.895 & 0.849 & 0.620 & 0.917 & 0.893 & 0.955 \\
\hline
\end{tabular}


Table 5: Theoretical Periurban Ecotourism Model: Regression Weight Estimates and Hypothesis Testing Results

\begin{tabular}{|c|c|c|c|c|c|c|c|}
\hline Input data & Variables & & & Estimate & S.E. & C.R.(t) & Testing result \\
\hline \multirow{3}{*}{ All participants } & $\begin{array}{l}\text { Overall } \\
\text { satisfaction }\end{array}$ & $\leftarrow$ & Destination image & 0.384 & 0.035 & $11.016^{\star \star \star}$ & Supported \\
\hline & $\begin{array}{l}\text { Overall } \\
\text { satisfaction }\end{array}$ & $\leftarrow$ & $\begin{array}{l}\text { Destination } \\
\text { awareness }\end{array}$ & 0.122 & 0.062 & $1.976^{\star \star}$ & Supported \\
\hline & $\begin{array}{l}\text { Overall } \\
\text { satisfaction }\end{array}$ & $\leftarrow$ & $\begin{array}{l}\text { Destination } \\
\text { uniqueness }\end{array}$ & 0.057 & 0.050 & 1.136 & Not supported \\
\hline \multirow[t]{2}{*}{$(\mathrm{N}=480)$} & $\begin{array}{l}\text { Destination } \\
\text { loyalty }\end{array}$ & $\leftarrow$ & Overall satisfaction & 1.106 & 0.078 & $14.147^{\star \star \star}$ & Supported \\
\hline & $\begin{array}{l}\text { Overall } \\
\text { satisfaction }\end{array}$ & $\leftarrow$ & Destination image & 0.338 & 0.047 & $7.142^{\star \star \star}$ & Supported \\
\hline \multirow[t]{2}{*}{$\begin{array}{l}\text { First } \\
\text { visitors }\end{array}$} & $\begin{array}{l}\text { Overall } \\
\text { satisfaction }\end{array}$ & $\leftarrow$ & $\begin{array}{l}\text { Destination } \\
\text { awareness }\end{array}$ & 0.122 & 0.086 & 1.416 & Not supported \\
\hline & $\begin{array}{l}\text { Overall } \\
\text { satisfaction }\end{array}$ & $\leftarrow$ & $\begin{array}{l}\text { Destination } \\
\text { uniqueness }\end{array}$ & 0.130 & 0.070 & $1.863^{\star}$ & Supported \\
\hline \multirow[t]{2}{*}{$(N=268)$} & $\begin{array}{l}\text { Destination } \\
\text { loyalty }\end{array}$ & $\leftarrow$ & Overall satisfaction & 1.062 & 0.104 & $10.204^{\star \star \star}$ & Supported \\
\hline & $\begin{array}{l}\text { Overall } \\
\text { satisfaction }\end{array}$ & $\leftarrow$ & Destination image & 0.402 & 0.050 & $8.109^{\star \star \star}$ & Supported \\
\hline \multirow[t]{2}{*}{$\begin{array}{l}\text { Repeat } \\
\text { visitors }\end{array}$} & $\begin{array}{l}\text { Overall } \\
\text { satisfaction }\end{array}$ & $\leftarrow$ & $\begin{array}{l}\text { Destination } \\
\text { awareness }\end{array}$ & 0.210 & 0.092 & $2.279^{\star \star}$ & Supported \\
\hline & $\begin{array}{l}\text { Overall } \\
\text { satisfaction }\end{array}$ & $\leftarrow$ & $\begin{array}{l}\text { Destination } \\
\text { uniqueness }\end{array}$ & -0.045 & 0.066 & -0.680 & Not supported \\
\hline$(\mathrm{N}=212)$ & $\begin{array}{l}\text { Destination } \\
\text { loyalty }\end{array}$ & $\leftarrow$ & Overall satisfaction & 1.225 & 0.122 & $10.078^{\star \star \star}$ & Supported \\
\hline
\end{tabular}

${ }^{\star \star \star} p<0.01 / * \star p<0.05 /{ }^{*} p<0.1$

matters is that the frequency of 'chartered bus' in the repeat visitor group is about twice as large as that of the first visitor group, and this seems to be related to the fact that the repeat visitor group had a relatively high frequency in 'tour group' as the travel party.

In terms of occupation, the first visitor group mostly consisted of 'clerical worker or civil servant' $(\mathrm{N}=107$, $37.9 \%)$, 'homemaker' $(\mathrm{N}=56,20.9 \%)$ and 'student' ( $\mathrm{N}=$ $37,13.8 \%$ ) in this order, and the repeat visitor group was mostly consisted of 'homemaker' $(\mathrm{N}=69,32.5 \%)$, 'clerical worker or civil servant' $(\mathrm{N}=57,26.9 \%)$ and 'others' $(\mathrm{N}=49$, $23.1 \%$ ) in this order.

The first visitor group showed relatively even distribution of ages: ' $10-20$ ' $(\mathrm{N}=96,35.8 \%)$, ' $30-40$ ' $(\mathrm{N}=71$, $26.5 \%)$, '50-60' $(\mathrm{N}=86,21.1 \%)$ in which case the high frequency of 10-20 seems to be related to the rate of students. Meanwhile, the repeat visitor group showed a high frequency in '50-60' amongst ' $10-20$ ' $(\mathrm{N}=27,12.7 \%)$, '30-40' $(\mathrm{N}=39,18.4 \%)$ and ' $50-60$ ' $(\mathrm{N}=109,51.4 \%)$. The high frequency of 50-60 appears to be related to the relatively high frequency of homemakers.

\section{Conclusion}

\subsection{Discussion and application}

Amid growing interest in ecosystems and increases in family tours in these years resulting in the growth of educational tourism activities, this study seeks to expand the concept of ecotourism, which draws attention as an alternative tourist activity or tourist commodity. Accordingly, in order to bring the concept of ecotourism to the fields of casual tourism activities enjoyed in nearby nature in everyday lives (e.g. hiking and water sports), this study proposed 'periurban ecotourism'. Furthermore, with the aim of identifying a structural relationship between key attribute dimensions of ecotourism destination considered by tourists taking part in 'periurban ecotourism' associated tourism activities (e.g. hiking and water sports) and overall satisfaction and destination loyalty of tourism activities, a 'theoretical periurban ecotourism model' was proposed to test the hypotheses. Results of 
Table 6: Differences in Characteristics between first visitors and repeat visitors

\begin{tabular}{|c|c|c|c|c|c|c|c|c|}
\hline \multirow[t]{2}{*}{ Contents } & & \multicolumn{2}{|c|}{ First visitor $(\mathrm{N}=\mathbf{2 6 8})$} & \multicolumn{2}{|c|}{$\begin{array}{l}\text { Repeat visitor } \\
(\mathrm{N}=212)\end{array}$} & \multicolumn{2}{|c|}{ Total (480) } & \multirow[t]{2}{*}{ Sig. } \\
\hline & & $\mathbf{N}$ & $\%$ & $\mathbf{N}$ & $\%$ & $\mathrm{~N}$ & $\%$ & \\
\hline \multirow[t]{11}{*}{ Home } & Osaka City, Osaka Prefecture & 27 & 10.1 & 13 & 6.1 & 40 & 8.3 & $0.000^{\star \star \star *}$ \\
\hline & Other, Osaka Prefecture & 46 & 17.2 & 32 & 15.1 & 78 & 16.3 & \\
\hline & Nagoya City, Aichi Prefecture & 22 & 8.2 & 18 & 8.5 & 40 & 8.3 & \\
\hline & Other, Aichi Prefecture & 48 & 17.9 & 25 & 11.8 & 73 & 15.2 & \\
\hline & Mie Prefecture & 40 & 14.9 & 86 & 40.6 & 126 & 26.3 & \\
\hline & Nara Prefecture & 22 & 8.2 & 18 & 8.5 & 40 & 8.3 & \\
\hline & Hyogo Prefecture & 20 & 7.5 & 6 & 2.8 & 26 & 5.4 & \\
\hline & Kyoto Prefecture & 8 & 3.0 & 4 & 1.9 & 12 & 2.5 & \\
\hline & Wakayama Prefecture & 2 & 0.7 & 0 & 0.0 & 2 & 0.4 & \\
\hline & Shiga Prefecture & 5 & 1.9 & 7 & 3.3 & 12 & 2.5 & \\
\hline & Other & 28 & 10.4 & 3 & 1.4 & 31 & 6.5 & \\
\hline \multirow{7}{*}{$\begin{array}{l}\text { Travel } \\
\text { party }\end{array}$} & Single & 24 & 9.0 & 21 & 9.9 & 45 & 9.4 & $0.005^{\star \star \star}$ \\
\hline & Family & 32 & 11.9 & 18 & 8.5 & 50 & 10.4 & \\
\hline & Husband and wife & 65 & 24.3 & 51 & 24.1 & 116 & 24.2 & \\
\hline & Couple & 49 & 18.3 & 19 & 9.0 & 68 & 14.2 & \\
\hline & Friends & 70 & 26.1 & 57 & 26.9 & 127 & 26.5 & \\
\hline & Tour group & 21 & 7.8 & 36 & 17.0 & 57 & 11.9 & \\
\hline & Other & 7 & 2.6 & 10 & 4.7 & 17 & 3.5 & \\
\hline \multirow[t]{9}{*}{ Motivation } & Newspaper or magazine & 25 & 9.3 & 10 & 4.7 & 35 & 7.3 & $0.000^{\star \star \star}$ \\
\hline & Internet & 36 & 13.4 & 22 & 10.4 & 58 & 12.1 & \\
\hline & Shell folder & 15 & 5.6 & 14 & 6.6 & 29 & 6.0 & \\
\hline & TV radio & 15 & 5.6 & 9 & 4.2 & 24 & 5.0 & \\
\hline & $\begin{array}{l}\text { Advice from a friend } \\
\text { (acquaintance) }\end{array}$ & 51 & 19.0 & 32 & 15.1 & 83 & 17.3 & \\
\hline & $\begin{array}{l}\text { Had a good experience on } \\
\text { the last visit }\end{array}$ & 2 & 0.7 & 84 & 39.6 & 86 & 17.9 & \\
\hline & Have never been there & 96 & 35.8 & 6 & 2.8 & 102 & 21.3 & \\
\hline & Business, homecoming & 5 & 1.9 & 2 & .9 & 7 & 1.5 & \\
\hline & Other & 23 & 8.6 & 33 & 15.6 & 56 & 11.7 & \\
\hline Traffic & Kintetsu Railways & 69 & 25.7 & 39 & 18.4 & 108 & 22.5 & $0.003^{* \star \star}$ \\
\hline \multirow[t]{6}{*}{ Facilities } & Private automobile & 157 & 58.6 & 121 & 57.1 & 278 & 57.9 & \\
\hline & Scheduled bus & 2 & 0.7 & 4 & 1.9 & 6 & 1.3 & \\
\hline & Rental car & 12 & 4.5 & 3 & 1.4 & 15 & 3.1 & \\
\hline & Chartered bus & 24 & 9.0 & 40 & 18.9 & 64 & 13.3 & \\
\hline & $J R$ & 2 & 0.7 & 0 & 0.0 & 2 & 0.4 & \\
\hline & Other & 2 & 0.7 & 5 & 2.4 & 7 & 1.5 & \\
\hline \multirow[t]{9}{*}{ Occupation } & Student & 37 & 13.8 & 9 & 4.2 & 46 & 9.6 & $0.000^{\star \star \star}$ \\
\hline & $\begin{array}{l}\text { Clerical worker or civil } \\
\text { servant }\end{array}$ & 107 & 39.9 & 57 & 26.9 & 164 & 34.2 & \\
\hline & Teacher & 2 & 0.7 & 2 & 0.9 & 4 & 0.8 & \\
\hline & Self-employed & 19 & 7.1 & 21 & 9.9 & 40 & 8.3 & \\
\hline & Skilled worker & 17 & 6.3 & 3 & 1.4 & 20 & 4.2 & \\
\hline & Homemaker & 56 & 20.9 & 69 & 32.5 & 125 & 26.0 & \\
\hline & Culture or art field & 0 & 0.0 & 1 & 0.5 & 1 & 0.2 & \\
\hline & Technology or science field & 2 & 0.7 & 1 & 0.5 & 3 & 0.6 & \\
\hline & Other & 28 & 10.4 & 49 & 23.1 & 77 & 16.0 & \\
\hline \multirow[t]{4}{*}{ Age } & $10-20$ & 96 & 35.8 & 27 & 12.7 & 123 & 25.6 & $.000^{\star \star \star}$ \\
\hline & $30-40$ & 71 & 26.5 & 39 & 18.4 & 110 & 22.9 & \\
\hline & $50-60$ & 86 & 32.1 & 109 & 51.4 & 195 & 40.6 & \\
\hline & 70 and older & 15 & 5.6 & 37 & 17.5 & 52 & 10.8 & \\
\hline
\end{tabular}

\footnotetext{
$\star \star \star p<0.01$
} 
testing 'theoretical periurban ecotourism model': destination image was found to be a key attribute dimension that affects overall satisfaction and destination awareness appeared to be a significant influence. However, it turned out that destination uniqueness is not statistically significant. These findings revealed that in Nabari, the subject of this study, tourists primarily visit natural sites such as the Akame 48 waterfalls, Kaochi valleys and Shorenji Lake as tourism activities, and it is a drawback of the city that there are not enough cultural, historical and other entertainment-related tourism resources besides nature. Moreover, there are competing destinations near Nabari, which offer scenic sites and tourism activities similar to those of Nabari. Consequently, destination image and awareness that visitors have towards the current natural environment appeared to be assessed positively to some degree, which led to a significant impact on overall satisfaction. Compared to other areas, nevertheless, the city lacked in uniqueness that makes it stand out from its competitors. This means, in turn, that the city desperately requires other attractions than nature to enhance the satisfaction of visitors. In this respect, Nabari City should consider the need of developing a variety of adventure programmes linked to its nature when exploring directions to develop into a site of ecotourism promoted by the city in the course of policy making.

It is also critical for the city to consider attributes of the first visitor and repeat visitor groups when developing policy directions for ecotourism. Given that potential visitors are characterised by their preference to individual tours with family, friends and couple, it is necessary to develop policies in terms of software covering education programmes and events for them. In addition, it is necessary to improve access to information through newspapers and magazines and current web sites and develop comprehensive promotion strategies to create new images of the area. Besides, emphasis should be given to policies to maintain visits of repeat visitors, the major visitor group at present. Given the characteristics of repeat visitors such as adults in their 50s and 60s and homemakers, tour courses focusing on themes of 'health' and 'healing and refresh' should be developed and closely connected to hot springs in operation now, to name a few detail plans.

When it comes to studies related to the direction of ecotourism development conducted so far, a community of the government (or local governments) and citizens, regional experts (NPOs, NGOs, etc.) and tour operators should be created to ensure sustainable development and operation of ecotourism and professional organisations should be formed, which have been suggested as the most important challenges (Welford and Ytterhus, 1998;
Burckley, 2000; Jones, 2005; Stronza and Gordillo, 2008). Thus, as a part of efforts to make a policy for ecotourism it pursues now, Nabari City also faces many challenges to grow into a sustainable ecotourism destination, including education of citizens, training of regional experts, promotion of cooperation with ecosystem preservation organisations (NPOs, NGOs, etc.) and formation of a strategic cooperative system with tour operators in nearby big cities.

In order to link findings from this study to strategies for ecotourism development of the city, it is most important to improve and make its destination image and awareness more positive. Detail strategies for this purpose may include promotion of diverse promotion campaigns to improve its destination image, increase in education and experience programmes and planning of specialised events. Amongst others, however, the city needs to differentiate itself from competing places nearby and to appeal its uniqueness to visitors, which cannot be achieved by the city (government) alone. All of the citizens of Nabari should cooperate actively with the city, believing that this is an important project that will provide strong economic and social effects. The current ecotourism whole promotion design of Nabari City (2014) sets four basic directions to promote tourism: preservation of natural tourist resources, utilisation of local resources, construction of infrastructure for tourism development and cooperation and linkage. In this framework, linkage between tourism and local industries, linkage with surrounding areas and association with various organisations should be defined as strategic tasks. Policy-making directions of this kind seem to be very positive, but active dialogue and exchange with officials are critical to make policies. Positively reflecting results of diverse research on visitors like this study on policy making is very important as well.

\subsection{Limitations and future research}

This study aims to expand the concept of ecotourism to cover ecotourism activities (hiking, etc.) in everyday lives as an exploratory research for various ecotourism studies to be conducted in the future. In Korea and Japan, people often visit nature (mountains, valleys and rivers) not far from their home over the weekend on one-day trips or short trips. Although these trips can be categorised into recreation, visits to natural sites designated by the government including national parks can be addressed in terms of a broader category of tourism activity rather than recreation. Therefore, this study proposes the 'periurban ecotourism' concept that expands the category of ecotourism much studied so far into natural environments that 
people have easy access to in their every lives and the tested hypotheses.

However, there are limitations of this study, for example, it fails to provide a firm theoretical ground for the proposed 'periurban ecotourism' concept. Researches categorising the ecotourism concept are not enough, which include a study of Weaver and Lawton (2002) which further classified the nature of ecotourism into hard (active, deep) and soft (passive, shallow) type and that of Weaver (2005) which further divided the concept into two types: comprehensive ecotourism and minimalist ecotourism. In addition, Buckley (2000) raised new issues related to ecotourism in the NEAT (nature, eco-and adventure tourism) study, and Wight (1996) segmented the ecotourism market into two types based on characteristics - General Consumers Interested in Ecotourism and Experienced Ecotourism Travellers, setting directions for ecotourism research.

Further studies are needed to develop a more in-depth theory of 'periurban ecotourism' to expand the concept of ecotourism and present more empirical findings regarding characteristics, lifestyles and motivations of ecotourists participating in 'periurban ecotourism' in order to drive efforts of various research on ecotourism and contribute to the sustainable development of the tourism industry in small- and medium-scale cities and areas having no tourist resources other than nature.

\section{References}

[1] Japan Tourism Agency. (2014). White paper on tourism 2013. http://www.mlit.go.jp/

[2] Ashworth, G., \& Page, S.J. (2011). Urban tourism research: Recent progress and current paradoxes. Tourism Management, 32, 1-15

[3] Pearce, D.G. (2001). An Integrative Framework for Urban Tourism Research. Annals of Tourism Research, 28(4), 926-946

[4] Beerli, A., \& Martín, J.D. (2004a). Factors Influencing Destination Image. Annals of Tourism Research, 31(3), 657-681

[5] Beerli, A., \& Martín, J.D. (2004b). Tourists' characteristics and the perceived image of tourist destinations: a quantitative analysis - a case study of Lanzarote, Spain. Tourism Management, 25, 623-636

[6] Chen, C.F., \& Tsai, D.C. (2007). How destination image and evaluative factors affect behavioral intentions. Tourism Management, 28, 1115-1122

[7] Ignacio, R. del Bosque., \& Martín H.S. (2008). Tourist Satisfaction A Cognitive-Affective Model. Annals of Tourism Research, 35(2), 551-573

[8] Chi, C.G.Q., \& Qu, H. (2008). Examining the structural relationship of destination image, tourist satisfaction and destination loyalty: An integrated approach. Tourism Management, 29, 624-636
[9] Weaver, D.B., \& Lawton L.J. (2007). Twenty years on: The state of contemporary ecotourism research. Tourism Management, 28, 1168-1179

[10] Sirakaya, E., Sasidharan, V., \& Sönmez, S. (1999). Redefining Ecotourism: The Need for a Supply-Side View. Journal of Travel Research, 38(Nov), 168-172

[11] Fennell, D.A. (2001). A content analysis of ecotourism definitions. Current Issues in Tourism, 4(5), 403-421

[12] Donohoe, H.M., \& Needham, R.D. (2006). Ecotourism: The Evolving Contemporary Definition. Journal of Ecotourism, 5(3), $192-210$

[13] Weaver, D.B. (2001). Ecotourism as Mass Tourism: Contradiction or Reality? Cornell Hotel and Restaurant Administration Quarterly, April, 104-112

[14] Weaver, D.B. (2005). Comprehensive and Minimalist Dimensions of Ecotourism. Annals of Tourism Research, 32(2), 439-455

[15] Wight, P.A. (1996). North American Ecotourism Market: Motivations, Preferences, and Destinations. Journal of Travel Research, Summer, 3-10

[16] TIES (The International Ecotourism Society). (1990). Ecotourism Definition. https://www.ecotourism.org/

[17] Campbell, L.M. (1999). Ecotourism in Rural Development Communities. Annals of Tourism Research, 26(3), 534-553

[18] Weaver, D.B. (1999). Magnitude of Ecotourism in Costa Rica and Kenya. Annals of Tourism Research, 26(4), 792-816

[19] Tepelus, C.M., \& Córdoba, R.C. (2005). Recognition schemes in tourism - from 'eco' to 'sustainability'? Journal of Cleaner Production, 13, 135-140

[20] Weaver, D.B., \& Lawton, L.J. (2002). Overnight Ecotourist Market Segmentation in the Gold Coast Hinterland of Australia. Journal of Travel Research, 40(February), 270-280

[21] Tsaur, S.H., Lin, Y.C., \& Lin, J.H. (2006). Evaluating ecotourism sustainability from the integrated perspective of resource, community and tourism. Tourism Management, 27, 640-653

[22] Shikida, A., Yoda, M., Kino, A., \& Morishige, M. (2010). Tourism relationship model and intermediary for sustainable tourism management: Case study of the Kiritappu Wetland Trust in Hamanaka, Hokkaido. Tourism and Hospitality Research, 10(2), 105-115

[23] Lee, Y.S., Lawton, L.J., \& Weaver, D.B. (2012). Evidence for a South Korean Model of Ecotourism. Journal of Travel Research, 52(4), 520-533

[24] Buckley, R. (1994). A Framework for Ecotourism. Annals of Tourism Research, 21(3), 661-665

[25] Buckley, R. (2000). Neat Trends: Current Issues in Nature, Eco-and Adventure Tourism. International Journal of Tourism Research, 2, 437-444

[26] Bramwell, B. (1998). User satisfaction and product development in urban tourism. Tourism Management, 19(1), 35-47

[27] Higham, J., \& Lück, M. (2002). Urban Ecotourism: A Contradiction in Terms? Journal of Ecotourism, 1(1), 36-51

[28] Gibson, A., Dodds, R., Joppe, M., \& Jamieson, B. (2003). Ecotourism in the city? Toronto's Green Tourism Association. International Journal of Contemporary Hospitality Management, 15(6), 324-327

[29] Wu, Y.Y., Wang, H.L., \& Ho, Y.F. (2010). Urban Ecotourism: Defining and assessing dimensions using fuzzy number construction. Tourism Management, 31, 739-743 
[30] Bigné, J.E., Sánchez, M.I., \& Sánchez J. (2001). Tourism image, evaluation variables and after purchase behavior: interrelationship. Tourism Management, 22, 607-616

[31] Chi, C.G.Q., \& Qu, H. (2008). Examining the structural relationship of destination image, tourist satisfaction and destination loyalty: An integrated approach. Tourism Management, 29, 624-636

[32] Assaker, G., Vinzi, V.E., \& O'Connor, P. (2011). Examining the effect of novelty seeking, satisfaction, and destination image on tourists' return pattern: A two factor, non-linear latent growth model. Tourism Management, 32, 890-901

[33] Prayag, G., \& Ryan, C. (2012). Antecedents of Tourists' Loyalty to Mauritius: The Role and Influence of Destination Image, Place Attachment, Personal Involvement, and Satisfaction. Journal of Travel Research, 51(3), 342-356

[34] Yoon, Y., \& Uysal, M. (2005). An examination of the effects of motivation and satisfaction on destination loyalty: a structural model. Tourism Management, 26, 45-56

[35] Aaker, D.A. (1996). Measuring Brand Equity across Products and Markets. California Management Review, 38(3), 102-120

[36] Keller, K.L. (1993). Conceptualizing, Measuring, and Managing Customer-Based Brand Equity. Journal of Marketing, 57(1), 1-22

[37] Lee, J.S., \& Back, K.J. (2008). Attendee-based brand equity. Tourism Management, 29, 331-344

[38] Lee, J.S., \& Back, K.J. (2010). Reexamination of attendee-based brand equity. Tourism Management, 31, 395-401

[39] Pike, P. (2007). Consumer-based brand equity for destination: Practical DMO performance measures. Journal of Travel Marketing, 22(1), 51-61

[40] Pike, P. (2007). Consumer-based brand equity for Australia as a long-haul tourism destination in an emerging market. International Marketing Review, 27(4), 434-449

[41] Netemeyer, R.G., Krishnan, B., Pullig, C., Wang, G., Yagci, M., Dean, D., Ricks, J., \& Wirth, F. (2004). Developing and validating measures of facets of customer-based brand equity. Journal of Business Research, 57, 209-224

[42] Hui, T.K., Wan, D., \& Ho, A. (2007). Tourists' satisfaction, recommendation and revisiting Singapore. Tourism Management, 28, 965-975

[43] Campo-Martínez, S., Garau-Vadell, J.B., \& Martínez-Ruiz, M.P. (2010). Factors influencing repeat visits to a destination: The influence of group composition. Tourism Management, 31, $862-870$

[44] Nabari City's Statistics book. (2014). http://www.city. nabari. lg.jp/

[45] Crompton, J.L. (1979). An Assessment of the Image of Mexico as a Vacation Destination and the Influence of Geographical Location upon the Image. Journal of Travel Research, 18(4), 18-23

[46] Kotler, N., Haide, D.H., \& Rein, I. (1994). Mercadotecnia de Localidades. Mexico: Diana

[47] Kemp, E., Childers, C.Y., \& Williams, K.H. (2012). Place Branding: creating self-brand connections and brand advocacy. Journal of Product \& Brand Management, 21(7), 508-515

[48] Hsu, C.H.C., Oh, H.M., \& Assaf, A.G. (2012). A Customer- Based Brand Equity Model for Upscale Hotels. Journal of Travel Research, 51(1), 81-93

[49] Buil, I., de Chernatony, L., \& Martínez, E. (2008). A crossnational validation of the consumer-based brand equity scale. Journal of Product \& Brand Management, 17(6), 384-392

[50] Yoo, B.H., \& Donthu, N. (2001). Developing and validating a multidimensional consumer-based brand equity scale. Journal of Business Research, 52, 1-14

[51] Kim, W.G., Jin-Sun B., \& Kim, H.J. (2008). Multidimensional Customer-Based Brand Equity and Its Consequences in Midpriced Hotels. Journal of Hospitality \& Tourism Research, 32(2), 235-254

[52] Boo, S.Y., Busser, J., \& Baloglu, S. (2009). A model of customer-based brand equity and its application to multiple destinations. Tourism Management, 30, 219-231

[53] Welford, R., \& Ytterhus, B. (1998), Conditions for the transformation of eco-tourism into sustainable tourism. European Environment, 8, 193-201

[54] Stronza, A., \& Gordillo, J. (2008). Community views of ecotourism. Annals of Tourism Research, 35(2), 448-468

[55] Jones, S. (2005). Community-based ecotourism: The significance of social capital. Annals of Tourism Research, 32(2), 303-324

[56] Nabari City. (2014). Nabari City's Ecotourism Whole Promotion Design. http://www.city.nabari.lg.jp/ 